\title{
PENGARUH FEE AUDIT, AUDIT TENURE, ROTASI AUDIT DAN REPUTASI AUDITOR TERHADAP KUALITAS AUDIT
}

\author{
(Studi Empiris Pada Perusahaan Manufaktur yang Terdaftar di Bursa Efek Indonesia Tahun
} 2013-2015)

\author{
Ninik Andriani ${ }^{1}$ \\ * Program Studi Akuntansi, Fakultas Ekonomi dan Bisnis Universitas Muhammadiyah Surakarta \\ *ninikandriani107@gmail.com ${ }^{1}$ \\ Nursiam $^{2}$ \\ * Program Studi Akuntansi, Fakultas Ekonomi dan Bisnis Universitas Muhammadiyah Surakarta \\ *nursiam@ums.ac.id ${ }^{2}$
}

\begin{abstract}
This study aimed to examine the effect of audit fee, audit tenure, audit rotation and auditor reputation on the audit quality in manufacturing companies listed in Indonesian Stock Exchange of 2013-2015. Population of the research is 117 manufacturing companies listed in Indonesian Stock Exchange of 2013-2015. Sample was taken by using purposive sampling, namely sampling with certain consideration. Based on the criteria, data sample of 37 manufacturing companies for period of three years were obtained, so that sample was 104 data. The data was analyzed by using descriptive statistic analysis and logistic regression analysis. The result shows that audit tenure, audit rotation and auditor reputation have no influences to the audit quality, and audit fee has significant effect on audit quality.
\end{abstract}

Keywords: audit fee, audit tenure, audit rotation, auditor reputation, audit quality

\section{Pendahuluan}

Di era globalisasi ini, dunia usaha telah berkembang dengan sangat pesat. hal ini membuat perusahaan sebagai suatu organisasi bertanggung jawab untuk semua peristiwa ekonomi atau transaksi keuangan yang terjadi dan merangkumnya ke dalam laporan keuangan perusahaan. Selain digunakan oleh perusahaan, hasil audit juga dapat digunakan oleh pihak luar perusahaan seperti calon investor, kreditor, Bapepam dan pihak lain yang terkait untuk menilai perusahaan dan mengambil keputusan-keputusan yang strategik yang berhubungan dengan perusahaan tersebut. Dari profesi akuntan publik masyarakat mengharapkan penilaian yang bebas dan tidak memihak terhadap informasi yang disajikan oleh manajemen perusahaan dalam laporan keuangan.

Laporan keuangan merupakan hasil akhir dari proses akuntansi yang berguna dalam pengambilan keputusan untuk penggunanya. Sudah menjadi kewajiban perusahaan untuk secara jujur tanpa manipulasi dan terbuka untuk mengekspose laporan keuangannya kepada pihak yang berkepentingan.
Tujuan menyeluruh dari audit laporan keuangan adalah untuk menyatakan pendapat apakah keuangan klien menyajikan secara wajar dalam semua hal yang material sesuai prinsip-prinsip yang berlaku wajar sesuai prinsip akuntansi (Indarto, 2011).

De Angelo (1981) mendefinisikan kualitas audit merupakan probabilitas bahwa auditor akan menemukan dan melaporkan pelanggaran pada sistem akuntansi klien. Sedangkan probabilitas untuk menemukan pelanggaran tergantung pada kemampuan teknis auditor, dan probabilitas melaporkan pelanggaran tergantung pada independensi auditor (Law Tjun-Tjun, Marpaung dan Setiawan, 2012).

Salah satu faktor eksternal yang mempengaruhi kualitas audit adalah fee audit. Dalam hal ini, diasumsikan bahwa auditor yang berkualitas lebih tinggi akan mengenakan fee audit yang lebih tinggi pula. Chi et al (2005) menyatakan bahwa lamanya hubungan auditor dengan kliennya akan mempengaruhi independensi auditor karena objektivitas menurun. Penerapan atas peraturan ketentuan rotasi wajib juga dilandasi alasan teoritis 
bahwa penerapan rotasi wajib bagi auditor dan Kantor Akuntan Publik diharapkan dapat meningkatkan independensi auditor baik secara tampilan maupun secara fakta. Pembatasan lamanya jangka waktu auditor melakukan pemeriksaan terhadap perusahaan klien diharapkan supaya tidak terjadi eskalasi komitmen auditor terhadap penyimpangan yang dilakukan oleh klien. Giri (2010) menyatakan bahwa KAP bereputasi menjelaskan adanya sikap independensi auditor dalam melaksanakan tugas audit. KAP yang mempunyai reputasi yang baik dinilai akan lebih efisien dalam melakukan proses audit dan akan menghasilkan informasi yang sesuai dengan kewajaran dari laporan keuangan perusahaan.

Penelitian ini merupakan pengembangan penelitian terdahulu yang dilakukan oleh Kurniasih dan Rohman (2014) dengan menambahkan satu variabel independen yaitu reputasi auditor dari penelitian Pamungkas (2014) yang berjudul Pengaruh Fee Audit, Rotasi KAP dan Reputasi Auditor terhadap Kualitas Audit. Tujuan dari penelitian ini adalah untuk menguji pengaruh fee audit, audit tenure, rotasi audit, dan reputasi auditor terhadap kualitas audit.

\section{Kajian Pustaka dan Pengembangan Hipotesis} Teori Keagenan (Agency Theory)

Menurut Jensen dan Meckling (1976) dalam Kurniasih dan Rohman (2014), mendefinisikan teori agensi sebagai hubungan keagenan suatu kontrak, dimana satu orang atau lebih (prinsipal) meminta pihak lainnya (agen) untuk melaksanakan sejumlah pekerjaan atas nama principal, yang melibatkan pendelegasian sebagian kewenangan pengambilan keputusan kepada agen. Karena kepentingan kedua pihak tidak selalu sejalan, maka sering terjadi benturan kepentingan antara prinsipal dengan agen sebagai pihak yang diserahi wewenang untuk mengelola perusahaan yang menyebabkan diperlukannya pihak ketiga yang independen untuk memeriksa dan memberikan assurance pada laporan keuangan yang dibuat oleh manajemen, yaitu seorang auditor.

\section{Kualitas Audit}

Audit adalah akumulasi dan evaluasi bukti tentang informasi untuk menentukan dan melaporkan tingkat kesesuaian antara informasi dan kriteria yang telah ditetapkan. Menurut Rosnidah (2010) kualitas audit adalah pelaksanaan audit yang dilakukan sesuai dengan standar sehingga mampu mengungkapkan dan melaporkan apabila terjadi pelanggaran yang dilakukan klien. Audit memiliki fungsi sebagai proses untuk mengurangi ketidakselarasan informasi yang terdapat antara manajer dan para pemegang saham dengan menggunakan pihak luar untuk memberikan pengesahan terhadap laporan keuangan.

\section{Opini Going Concern}

Dalam penelitian ini, opini going concern digunakan sebagai proksi variabel kualitas audit. Going Concern dapat didefinisikan sebagai kelangsungan hidup suatu entitas (Novalinda, 2012). Dalam akuntansi going concern diartikan kemampuan perusahaan untuk dapat mempertahankan kegiatan usahanya dan terus berfungsi sebagai entitas bisnis.

\section{Fee Audit}

Fee audit merupakan fee yang diterima oleh akuntan publik setelah melaksanakan jasa auditnya, besarnya tergantung dari resiko penugasan, kompleksitas jasa yang diberikan, tingkat keahlian yang diperlukan untuk melaksanakan jasa tersebut, struktur biaya KAP yang bersangkutan.

\section{Audit Tenure}

Tenure adalah masa perikatan audit antara KAP dan klien terkait jasa audit yang telah disepakati sebelumnya. Tenure menjadi perdebatan pada saat masa audit tenure yang dilakukan secara singkat dan masa audit tenure yang dilakukan dalam jangka waktu lama. Hamid (2013) berpendapat bahwa dengan masa tenure yang singkat dimana saat auditor mendapatkan klien baru, membutuhkan tambahan waktu bagi auditor dalam memahami klien dan lingkungan bisnisnya. Masa tenure yang singkat mengakibatkan perolehan informasi berupa data dan bukti-bukti menjadi terbatas sehingga jika terdapat data yang salah atau data yang sengaja dihilangkan oleh manajer sulit ditemukan.

\section{Rotasi Audit}

Rotasi audit merupakan pergantian akuntan publik dimana akuntan publik di Indonesia hanya dapat mengaudit laporan keuangan perusahaan maksimal 3 tahun berturut-turut. 


\section{Reputasi Auditor}

Giri (2010) menyatakan bahwa KAP bereputasi menjelaskan adanya sikap independensi auditor dalam melaksanakan tugas audit. KAP besar identik dengan KAP bereputasi tinggi, dalam hal ini menunjukkan kemampuan auditor untuk bersikap independen dalam melaksanakan audit secara profesional sebab KAP menjadi kurang tergantung secara ekonomi kepada klien.

\section{Pengembangan Hipotesis}

Pengaruh Fee Audit Terhadap Kualitas Audit

Fee audit adalah fee yang diterima auditor yang berasal dari pembayaran oleh manajemen atau klien atas jasa audit yang telah dilakukan (Hartadi, 2012). Gammal (2012) membuktikan bahwa perusahaan multinasional dan bank-bank di Lebanon lebih memilih untuk membayar biaya audit yang bernominal besar dengan alasan yaitu mereka lebih mencari auditor yang dapat menghasilkan audit yang berkualitas.

Yuniarti (2011) dalam Kurniasih dan Rohman (2014) membuktikan bahwa biaya audit berpengaruh secara signifikan terhadap kualitas audit. Biaya yang lebih tinggi akan meningkatkan kualitas audit, karena biaya audit yang diperoleh dalam satu tahun dan estimasi biaya operasional yang dibutuhkan untuk melaksanakan proses audit dapat meningkatkan kualitas audit. Sehingga hipotesisnya dapat dirumuskan sebagai berikut ini:

$\mathrm{H}_{1}$ : Fee Audit berpengaruh positif terhadap kualitas audit

\section{Pengaruh Audit Tenure Terhadap Kualitas Audit}

Masa perikatan yang terlalu singkat waktunya dapat menyebabkan pengetahuan spesifik tentang klien masih sedikit sehingga kualitas audit rendah. Jika terlampau panjang bisa menyebabkan turunnya independensi dan obyektivitas akibat keakraban berlebihan antara kedua belah pihak (Permana, 2012).

Penelitian yang dilakukan oleh Giri (2010) membuktikan bahwa variabel audit tenure berpengaruh negatif dan signifikan terhadap kualitas audit, sedangkan menurut penelitian Permana (2012) bahwa audit tenure tidak berpengaruh terhadap kualitas audit. Sehingga hipotesisnya dapat dirumuskan sebagai berikut ini:

$\mathrm{H}_{2}$ : Audit Tenure berpengaruh terhadap kualitas audit.

Pengaruh Rotasi Audit Terhadap Kualitas Audit

Kewajiban rotasi dalam perspektif teori agensi dimana teori ini menggambarkan keberadaan perusahaan. Pihak perusahaan sebaiknya melakukanrotasi audit partner, sesuai dengan Peraturan Menteri Keuangan No.17 tahun 2008 tentang "Jasa Akuntan Publik" yaitu seorang Akuntan Publik paling lama 3 (tiga) tahun buku berturut-turut.

Menurut penelitian Kurniasih dan Rohman (2014) membuktikan bahwa terdapat pengaruh positif dan signifikan antara rotasi audit dengan kualitas audit, sedangkan menurut penelitian Hartadi (2012) menyatakan bahwa rotasi audit tidak berpengaruh terhadap kualitas audit. Sehingga hipotesisnya dapat dirumuskan sebagai berikut:

$\mathrm{H}_{3 \text { : }}$ Rotasi Audit berpengaruh terhadap kualitas audit.

\section{Pengaruh Reputasi Auditor Terhadap Kualitas Audit}

Reputasi auditor dalam beberapa penelitian sebelumnya dilihat dari sudut pandang yang berbeda. Beberapa ada yang mengukur berdasarkan banyaknya auditor tertentu disewa oleh manajer, dan penelitian lain ada yang mengukur berdasarkan reputasi auditor dalam KAP yang berafiliasi dengan KAP Big Four atau non Big Four. KAP Big Four menjadi ukuran reputasi bagi sebuah KAP. Artinya adalah dengan menggunakan jasa audit pada KAP yang berafiliasi dengan KAP Big Four, maka kualitas audit juga diharapkan dapat lebih baik dari pada KAP yang tidak berafiliasi dengan KAP Big Four.

Menurut penelitian yang dilakukan Giri (2010) menemukan bukti bahwa KAP yang berafiliasi dengan KAP international berpengaruh terhadap kualitas audit, sedangkan dalam penelitian Hartadi (2012) menemukan bukti bahwa reputasi auditor tidak berpengaruh signifikan terhadap kualitas audit. Sehingga hipotesisnya dapat dirumuskan sebagai berikut:

$\mathrm{H}_{4}$ : Reputasi Auditor berpengaruh terhadap kualitas audit.

\section{Metode Penelitian}




\section{Desain Penelitian}

Penelitian ini merupakan penelitian kuantitatif dengan melakukan pengujian hipotesis. Data yang digunakan adalah data sekunder dengan melihat laporan tahunan perusahaan manufaktur yang terdaftar di Bursa Efek Indonesia (BEI) selama tahun 20132015.

\section{Populasi, Sampel Dan Teknik Pengambilan Sampel}

Populasi dalam penelitian ini adalah perusahaan manufaktur yang terdaftar di Bursa Efek Indonesia tahun 2013-2015. Pada penelitian ini teknik pengambilan sampel menggunakan metode purposive sampling. Purposive sampling adalah pengambilan sampel yang dilakukan dengan memberikan syarat atau kriteria. Kriteria yang digunakan untuk memilih sampel adalah sebagai berikut: (1) Perusahaan Manufaktur yang menerbitkan laporan keuangan auditan secara berturut-turut untuk periode tahun 2013-2015; (2) Perusahaan Manufaktur yang menggunakan mata uang rupiah dalam pelaporan laporan keuangan periode tahun 2013-2015; (3) Perusahaan Manufaktur yang memiliki data dan informasi lengkap yang digunakan untuk menganalisis faktor-faktor yang mempengaruhi kualitas audit tahun 2013-2015; (4) Laporan keuangan diaudit oleh auditor independen.

\section{Jenis, Sumber dan Metode Pengumpulan Data}

Data yang digunakan dalam penelitian ini adalah data sekunder. Adapun data sekunder dalam penelitian ini diperoleh dari laporan tahunan perusahaan manufaktur yang terdaftar di Bursa Efek Indonesia tahun 2013 sampai tahun 2015 melalui akses langsung dari website Indonesia Stock Exchange (www.idx.co.id).. Metode pengumpulan data yang digunakan dalam penelitian ini adalah metode dokumentasi yaitu metode pengumpulan data dengan mengumpulkan data sekunder berupa catatan-catatan atau dokumen sesuai dengan data yang diperlukan. Data yang dimaksud adalah laporan keuangan tahunan perusahaan yang terdaftar di BEI.

\section{Definisi Operasional Variabel dan Pengukurannya Variabel Dependen Kualitas Audit}

Kualitas audit merupakan kemampuan auditor untuk menemukan dan mengungkapkan kesalahan atau kekeliruan yang terdapat pada sistem akuntansi klien. Kualitas audit dalam penelitian ini diproksikan dengan opini Going Concern . variabel kualitas audit diukur dengan menggunakan variabel dummy dengan melihat kecenderungan auditor untuk menerbitkan opini Going Concern.

\section{Variabel Independen \\ Fee Audit}

Fee audit merupakan pendapatan yang didapatkan auditor sebagai imbalan atas jasa setelah dilakukannya audit. Fee audit dalam penelitian ini diproksikan dengan profesional fees yang tercantum dalam laporan keuangan perusahaan yang terdaftar di Bursa Efek Indonesia. Kemudian variabel ini dihitung dengan menggunakan logaritma natural (Kurniasih dan Rohman, 2014).

\section{Audit Tenure}

Audit tenure merupakan lamanya masa perikatan auditor dengan klien. Semakin panjang masa perikatan antara klien dan auditor membuat adanya kedekatan emosional antara klien dan auditor sehingga mampu mengurangi tingkat objektifitas auditor dalam melaksanakan kegiatan auditnya. Masa perikatan audit tersebut diukur dengan menghitung jumlah tahun auditor melakukan perikatan dengan perusahaan yang sama secara berturut-turut (Sinaga, 2012).

\section{Rotasi Audit}

Rotasi audit adalah pergantian Kantor Akuntan Publik yang dilakukan oleh perusahaan. Sesuai dengan Peraturan Menteri Keuangan No.17 tahun 2008 tentang "Jasa Akuntan Publik". Kantor akuntan publik hanya boleh mengaudit perusahaan yang sama selama lima tahun berturut-turut dan tiga tahun berturut-turut untuk seorang akuntan publik. Namun ada beberapa perusahaan yang melakukan pergantian auditor sebelum lima tahun berturut-turut (voluntary). Rotasi audit diukur dengan menggunakan variabel dummy, 1 jika perusahaan melakukan rotasi dan 0 jika tidak melakukan rotasi.

\section{Reputasi Auditor}

Reputasi auditor adalah ukuran yang menunjukkan kemampuan auditor untuk bersikap independen dan melaksanakan audit secara profesional Giri (2010). Reputasi auditor diukur dengan menggunakan variabel dummy. Untuk auditor yang 
berasal dari KAP yang berafiliasi dengan KA円urilgh Sampel Penelitian

104

Four maka nilainya 1, dan untuk KAP Non Big Four

Sumber: Hasil olah data, 2017

nilainya 0 .

\section{Metode Analisis Data}

Dalam penelitian ini, pengujian dilakukan dengan menggunakan model regresi logistik. Regresi logistik adalah model regresi yang digunakan untuk menguji apakah probabilitas variabel terikat dapat diprediksi dengan variabel bebasnya (Ghozali, 2011). Model regeresi logistik yang digunakan adalah:

$$
\mathbf{K A}=\alpha+\beta_{1} \mathbf{F A}+\beta_{2} \mathbf{A T}+\beta_{3} \mathbf{R A}+\beta_{4} \mathbf{R E}+\ell
$$

\section{Keterangan :}

KA $=$ Kualitas Audit

$\boldsymbol{\alpha} \quad=$ Konstanta

$\boldsymbol{\beta}_{\mathbf{1}}-\boldsymbol{\beta}_{\mathbf{4}}=$ Koefisien Regresi

FA $=$ Fee Audit

AT $=$ Audit Tenure

RA $=$ Rotasi Audit

RE $=$ Reputasi Auditor

l= error

\section{Hasil dan Pembahasan}

Penelitian ini menggunakan laporan keuangan perusahaan Manufaktur yang terdaftar di Bursa Efek Indonesia tahun 2013-2015. Pengambilan sampel menggunakan metode purposive sampling dengan berbagai kriteria-kriteria yang sudah ditentukan diperoleh sampel sebanyak 104 perusahaan manufaktur.

Tabel IV.1

Penentuan Jumlah Sampel

Perusahaan manufaktur yang terdaftar di BEI Jumlah

selama tahun 2013-2015

Perusahaan manufaktur yang tidak menerbitkan laporan keuangan secara berturut-turut pada periode tahun 2013-2015

Perusahaan manufaktur yang tidak menggunakan mata uang rupiah dalam pelaporan laporan keuangan periode tahun 2013-2015

Perusahaan manufaktur yang tidak memiliki data dan informasi lengkap yang dibutuhkan

Laporan keuangan yang tidak diaudit oleh auditor independen

Sampel Penelitian

Jumlah sampel ( 37 x 3 tahun)

Outlier

\section{Hasil Penelitian \\ Statistik Deskriptif}

Analisis deskriptif digunakan untuk memberikan deskripsi suatu data yang dilihat dari ratarata (mean), standar deviasi (standard deviation), dan maksimum-minimum. Hasil pengujian dari 104 yang merupakan laporan keuangan 37 perusahaan manufaktur yang terdaftar di Bursa Efek Indonesia tiga tahun berturut-turut tahun 2013-2015 menunjukkan hasil sebagai berikut:

Tabel IV.2

Analisis Statistik Deskriptif

\begin{tabular}{llrrrr}
\hline & & & & & $\begin{array}{c}\text { Std. } \\
\text { Deviation }\end{array}$ \\
\hline KA & 104 & 0 & 1,00 & 0,1058 & 0,30903 \\
FA & 104 & 18,09 & 25,55 & 21,6741 & 1,80220 \\
AT & 104 & 1,00 & 3,00 & 1,2500 & $.0,53517$ \\
RA & 104 & 0 & 1,00 & 0,4615 & 0,50093 \\
RE & 104 & 0 & 1.00 & 0,1154 & 0,32103 \\
Valid N & 104 & & & & \\
(listwise) & & & & & \\
\hline
\end{tabular}

Sumber: Hasil olah data, 2017

Dari pengujian analisis statistik deskriptif diatas menunjukkan nilai kualitas audit yang diproksikan dengan opini going concern yang menggunakan metode variabel dummy memiliki nilai rata-rata (mean) sebesar 0,1058 dan nilai standar deviasi sebesar 0,30903 dengan nilai minimum 0 dan maksimum 1 yang berarti bahwa perusahaan dalam evaluasi bukti tentang informasi untuk menentukan dan melaporkan tingkat kesesuaian antara informasi dan kriteria yang telah ditetapkan auditor.

Variabel fee audit yang diproksikan dengan besarnya profesional fee yang dikeluarkan oleh perusahaan setiap tahunnya lalu dihitung menggunakan logaritma natural. Dari tabel analisis deskriptif didapatkan nilai mean sebesar 21,6741 dengan nilai maksimum 25,55 dan nilai minimum sebesar 18,09. Nilai median yang didapat dari nilai maksimum $(25,55)$ dan nilai minimum $(18,09)$ kemudian dibagi menunjukkan nilai sebesar 21,82, 
dengan nilai mean yang lebih tinggi dari median, dapat disimpulkan bahwa rata-rata perusahaan membayar dengan fee audit yang tinggi.

Variabel berikutnya adalah audit tenure diukur dengan lamanya suatu perusahaan diaudit oleh Kantor Akuntan Publik yang sama tahun buku berturut-turut, penelitian ini melihat dari tahun 2013-2015. Nilai mean pada analisis statistik diperoleh sebesar 1,2500 dengan nilai maksimum 3 dan nilai minimum 1, ini menunjukkan bahwa setiap perusahaan rata-rata diaudit oleh Kantor Akuntan Publik yang sama antara 2 sampai 3 tahun berturut-turut.

Variabel ketiga adalah rotasi audit yang diukur dengan menggunakan metode variabel dummy dimana nilai maksimal adalah 1 dan nilai minimumnya 0 . Pada hasil analisis deskriptif tersebut menunjukkan nilai mean sebesar 0,4615 dan nilai standar deviasi sebesar 0,50093, dengan demikian membuktikan bahwa kewajiban rotasi dalam perspektif menggambarkan keberadaan perusahaan yang sebaiknya melakukan rotasi audit partner.

Variabel terakhir adalah reputasi auditor yang juga diukur dengan menggunakan variabel dummy dengan nilai maksimum 1 dan nilai minimum 0 . Nilai mean yang dihasilkan sebesar 0,1154 dan nilai standar deviasi sebesar 0,32103 dengan demikian membuktikan bahwa perusahaan dalam menggunakan jasa auditor berdasarkan pada KAP yang berafiliasi dengan KAP Big Four dan KAP Non Big Four.

\section{Uji Hipotesis Penelitian}

\section{Menilai Model Fit (Overall Model Fit Test)}

Analisis inferensial pertama yang dilakukan adalah menilai overall model fit terhadap data penelitian. Peneliti menggunakan estimasi parameter untuk menentukan nilai Maximum Likehood Estimation (MLE).

Tabel IV.3

-2 Log Likehood (Overall Fit Model)

\begin{tabular}{cc}
\hline Keterangan & Nilai -2 Log L \\
\hline Block Number $=0$ (Awal) & 73,758 \\
Block Number = 1 (Akhir) & 62,621 \\
\hline
\end{tabular}

Sumber: Hasil olah data, 2017

Untuk tahap pengujian ini dilakukan dengan membandingkan antara nilai -2 Log Likehood (2LL) pada awal (Block Number $=0$ ) dengan nilai -2 Log Likehood (-2LL) pada akhir (Block Number $=1$ ). Nilai -2LL awal adalah sebesar 73,758, setelah semua data dimasukkan untuk empat varibel independen, maka nilai -2LL sebesar 62,621. Adanya penurunan likehood (-2LL) ini berarti model regresi yang lebih baik atau dengan kata lain model fit

\section{Menganalisa Koefisien Determinasi (Nagelkerke R Square)}

Analisis yang kedua adalah menganalisis koefisien determinasi (Nagelkerke $\mathrm{R}$ Square) sebagaimana terlihat dalam tabel ini:

Tabel IV.4

\begin{tabular}{ccc}
\multicolumn{3}{c}{ Nilai Nagelkerke R Square } \\
\hline-2 Log & Nilai & Nilai \\
Likehood & $\begin{array}{c}\text { Cox \& Snell R } \\
\text { Square }\end{array}$ & $\begin{array}{c}\text { Nagelkerke R } \\
\text { Square }\end{array}$ \\
\hline 62,621 & 0,074 & 0,150
\end{tabular}

Sumber: Hasil olah data, 2017

Pada tabel diatas menunjukkan bahwa nilai Nagelkerke R Square adalah sebesar 0,150 yang berarti bahwa variabilitas variabel dependen yang dapat dijelaskan oleh variabel independen sebesar $15,0 \%$ dan sisanya dijelaskan oleh variabel-variabel diluar model penelitian sebesar $85 \%$. Hal tersebut menunjukkan bahwa variabilitas variabel fee audit, audit tenure, rotasi audit dan reputasi auditor dapat menjelaskan variabel kualitas audit sebesar $15 \%$.

\section{Menilai Kelayakan Model Regresi (Hosmer and Lemeshow Test)}

Analisis ketiga yaitu dengan menggunakan Hosmer and Lemeshow Test yang diukur menggunakan nilai chi-square. Jika nilai Hosmer Lemeshow signifikan atau lebih kecil dari 0,05, maka hipotesis nol ditolak dan model dikatakan tidak fit, sebaliknya jika tidak signifikan maka hipotesis nol tidak dapat ditolak yang berarti data empiris sama dengan model atau model dikatakan fit (Ghozali, 2005:224). 
Tabel IV.5

Kelayakan Model Regresi

Hosmer and

Lemeshow Test

\begin{tabular}{ccc}
\hline Chi Square & Df & Sig \\
11,900 & 8 & 0,156 \\
\hline
\end{tabular}

Sumber: Hasil olah data, 2017

Tabel menunjukkan bahwa nilai pengujian Hosmer and Lemeshow Test sebesar 0,156. Karena nilai signifikansi lebih besar dari 0,05 (5\%), maka dapat disimpulkan bahwa hipotesis nol tidak câpat ditolak yang berarti bahwa model mampu memprediksi nilai observasinya atau dapat dikatakan bahwa model diterima karena sesuai dengan Rdata $^{\text {data }}$ observasinya.

Matrik Klasifikasi

Matrik klasifikasi menunjukkan kekGathsta prediksi dari model regresi untuk memprediksi kemungkinan kualitas audit pada perusahaan manufaktur di BEI:

Tabel IV.6 Matrik Klasifikasi

\begin{tabular}{|c|c|c|c|c|c|}
\hline & & & Predicted & & \\
\hline & Observed & K & & & \\
\hline & & Tidak menerima & Menerima & & Correct \\
\hline $\mathrm{KA}$ & Tidak menerima & 9 & & 0 & 100,0 \\
\hline & Menerima & 1 & & 0 & 0 \\
\hline Overall $\mathrm{Per}$ & intage & & & & 89,4 \\
\hline
\end{tabular}

Sumber :Hasil olah data, 2017

Dari tabel tersebut diketahui bahwa kekuatan prediksi dari model regresi secara keseluruhan adalah sebesar $89,4 \%$. Kekuatan prediksi model regresi untuk memprediksi penerimaan opini going concern pada perusahaan adalah sebesar (0\%). Hal ini menunjukkan hasil observasi dengan menggunakan model regresi ini tidak ada perusahaan $0 \%$ yang diprediksi menerima opini going concern dari total 11 perusahaan yang menerima opini going concern. Sedangkan kekuatan prediksi model hasil audit yang tidak menerima opini going concern sebesar 100\% yang berarti bahwa dengan model regresi yang digunakan ada 93 hasil audit yang tidak menerima.

\section{Model Regresi Logistik}

Pengujian hipotesis menggunakan regresi logistik, yaitu untuk menguji pengaruh fee audit, audit tenure, rotasi audit dan reputasi auditor terhadap kualitas audit. Hasil pengujian hipotesis dalam penelitian ini disajikan sebagai berikut:

Tabel IV.7

Uji Model Regresi Logistik

\begin{tabular}{llllll} 
B & S.E & Wald & df & Sig. & Keterangan \\
\hline 0,407 & 0,198 & 4,236 & 1 & 0,040 & H1 Diterima \\
$-2,317$ & 1,965 & 1,391 & 1 & 0,238 & H2 Ditolak \\
$-0,773$ & 0,734 & 1,109 & 1 & 0,292 & H3 Ditolak \\
2,195 & 2,093 & 1,100 & 1 & 0,294 & H4 Ditolak \\
$-8,400$ & 4,491 & 3,498 & 1 & 0,061 &
\end{tabular}

Sumber: Hasil olah data, 2017

Adapun model yang dihasilkan dari pengujian terhadap model regresi tersebut adalah:

$$
\begin{gathered}
K A=-8,400+0,407 F A-2,317 A T-0,773 R A+2,195 \\
R E+\ell
\end{gathered}
$$

Model diatas dapat diinterpretasikan sebagai berikut:

a. Konstanta sebesar -8,400 dengan arah koefisien yang negatif. Hal ini menunjukkan bahwa apabila variabel fee audit, audit tenure, rotasi audit dan reputasi auditor tidak berubah atau konstan, maka kualitas audit akan mengalami penurunan.

b. Nilai koefisien regresi variabel fee audit (FA) adalah sebesar 0,407 dengan parameter positif. Hal ini dapat diartikan setiap terjadi peningkatan 1 pada fee audit, maka peluang terjadinya kualitas audit perusahaan akan meningkat.

c. Nilai koefisien regresi variabel audit tenure (RA) adalah sebesar -2,317 dengan parameter negatif. Hal ini dapat diartikan setiap terjadi peningkatan 1 tahun pada audit tenure, maka peluang terjadinya kualitas audit perusahaan akan menurun. 
d. Nilai koefisien regresi variabel rotasi audit (RA) adalah sebesar $-0,773$ dengan parameter negatif. Hal ini dapat diartikan setiap terjadi peningkatan 1 kali rotasi audit, maka peluang terjadinya kualitas audit perusahaan akan menurun.

e. Nilai koefisien regresi variabel reputasi auditor (RE) adalah sebesar 2,915 dengan parameter positif. Hal ini dapat diartikan semakin tinggi reputasi auditor, maka peluang terjadinya kualitas audit perusahaan akan meningkat.

\section{Uji Wald}

Pengujian ini dilakukan untuk menguji apakah variabel-variabel independen secara simultan berpengaruh terhadap variabel dependen. Sehingga diperoleh hasil sebagai berikut:

Variabel Fee Audit diperoleh nilai wald sebesar 4,236 dengan signifikansi sebesar 0,040 yang lebih kecil dari $\alpha(5 \%)$. Jadi dapat disimpulkan bahwa Fee Audit berpengaruh terhadap Kualitas Audit.

Variabel Audit Tenure diperoleh nilai wald sebesar 1,391 dengan signifikansi sebesar 0,238 yang lebih besar dari $\alpha(5 \%)$. Jadi dapat disimpulkan bahwa Audit Tenure tidak berpengaruh terhadap Kualitas Audit.

Variabel Rotasi Audit diperoleh nilai wald sebesar 1,109 dengan signifikansi yang lebih besar dari $\alpha$ (5\%). Jadi dapat disimpulkan bahwa Rotasi Audit tidak berpengaruh terhadap Kualitas Audit.

Variabel Reputasi Auditor diperoleh nilai wald sebesar 1,100 dengan signifikansi0,294 yang lebih besar dari $\alpha$ (5\%). Jadi dapat disimpulkan bahwa Reputasi Auditor tidak berpengaruh terhadap Kualitas Audit.

\section{Pembahasan}

\section{Pengaruh Fee Audit Terhadap Kualitas Audit}

Variabel fee audit menunjukkan tingkat signifikansi sebesar 0,040 yang lebih kecil dari nilai koefisien $\alpha$ sebesar $5 \%(0,05)$ yang artinya hipotesis pertama diterima. Penelitian ini mendukung penelitian Kurniasih dan Rohman (2014) dan Hartadi (2012) yang membuktikan bahwa fee audit berpengaruh terhadap kualitas audit.

Kantor Akuntan Publik (KAP) yang berkualitas biasanya menghasilkan laporan audit yang berkualitas juga. Kantor Akuntan Publik besar (Big Four) memiliki kecenderungan fee audit yang dibebankan oleh perusahaan klien lebih besar dibandingkan dengan auditor KAP Non Big Four. Biaya audit yang lebih tinggi akan meningkatkan kualitas audit, karena biaya audit yang diperoleh dalam satu tahun dan estimasi biaya operasional yang dibutuhkan untuk melaksanakan proses audit dapat meningkatkan kualitas audit.

\section{Pengaruh Audit Tenure Terhadap Kualitas Audit}

Variabel audit tenure menunjukkan nilai signifikansi 0,238 lebih besar dari nilai $\alpha$ sebesar 5\% $(0,05)$. Karena nilai signifikansi lebih besar dari nilai $\alpha$ maka hipotesis kedua penelitian ini ditolak. Jadi penelitian ini menunjukkan bahwa audit tenure tidak berpengaruh terhadap kualitas audit. Hasil penelitian ini konsisten dengan penelitian Permana (2012) yang menyatakan bahwa audit tenure tidak berpengaruh terhadap kualitas audit.

Adanya penolakan atas hipotesis ini dikarenakan masa perikatan audit bukan patokan bahwa hasil audit akan berkualitas. Lamanya masa perikatan audit seharusnya Kantor Akuntan Publik lebih mengerti kondisi perusahaan klien sehingga tahu jika klien ingin memanipulasi laporan keuangan, tetapi karena masa perikatan yang lama juga Kantor Akuntan Publik (KAP) merasa percaya dengan klien sehingga tidak mengembangkan strategi prosedur audit yang digunakan dan menurunkan kualitas audit.

\section{Pengaruh Rotasi Audit Terhadap Kualitas Audit}

Variabel rotasi audit menunjukkan tingkat signifikansi 0,292 yaitu lebih besar dari koefisien $\alpha$ 0,05 yang berarti hipotesis ketiga penelitian ini tidak dapat diterima yaitu rotasi audit tidak berpengaruh terhadap kualitas audit. Hasil ini konsisten dengan hasil penelitian Hartadi (2012) yang membuktikan bahwa rotasi audit tidak berpengaruh terhadap kualitas audit. Nilai koefisien regresi yang negatif menunjukkan adanya hubungan berlawanan arah yang berarti semakin jarang perusahaan melakukan rotasi audit, semakin baik hasil audit yang dihasilkan.

Dalam penelitian ini membuktian bahwa melakukan rotasi audit bukan jaminan untuk menghasilkan hasil audit yang berkualitas. Menurut Hartadi (2012) hal ini disebabkan karena pasar sebenarnya tidak terlalu peduli apakah auditor yang menyatakan opini pada laporan keuangan tahunan tersebut pernah dirotasi atau tidak. 


\section{Pengaruh Reputasi Auditor Terhadap Kualitas Audit}

Variabel reputasi auditor menunjukkan tingkat signifikansi 0,294 yaitu lebih besar dari nilai $\alpha$ sebesar $5 \%(0,05)$. Karena nilai signifikansi lebih besar dari nilai $\alpha$ maka hipotesis terkahir penelitian tidak dapat diterima yaitu reputasi auditor tidak berpengaruh terhadap kualitas audit. Hasil ini konsisten dengan hasil penelitian Hartadi (2012) yang membuktikan bahwa reputasi auditor tidak berpengaruh terhadap kualitas audit.

Astrini (2013) menyatakan bahwa investor akan lebih percaya pada data akuntansi yang dihasilkan dari auditor yang bereputasi. Untuk itu jika perusahaan telah menggunakan KAP yang bereputasi, perusahaan tidak akan mengganti auditornya, walaupun fee yang ditawarkan KAP besar (Big Four) lebih tinggi dibandingkan Kap kecil (non Big Four). Karena KAP yang berskala besar mempunyai kemampuan melakukan penugasan audit yang lebih tinggi dibandingkan auditor berskala kecil sehingga mampu menghasilkan kualitas audit yang lebih baik.

\section{Simpulan}

Penelitian ini dilakukan untuk mengetahui pengaruh atas fee audit, audit tenure, rotasi audit dan reputasi auditor terhadap kualitas audit pada perusahaan manufaktur yang terdaftar di Bursa Efek Indonesia tahun 2013-2015.

Berdasarkan pembahasan yang sudah dilakukan di bab sebelumnya, maka kesimpulan yang dapat ditarik untuk menjawab rumusan masalah adalah sebagai berikut:

1. Fee audit berpengaruh terhadap kualitas audit. Hal ini menunjukkan bahwa semakin tinggi nilai fee audit yang diberikan oleh perusahaan, maka semakin meningkatkan kualitas audit. Adanya fee audit yang tinggi ini memungkinkan Kantor Akuntan Publik untuk melaporkan prosedur audit dengan lebih rinci dan lebih mendalam sehingga kualitas audit yang dihasilkan juga tinggi.

2. Audit tenure tidak berpengaruh terhadap kualitas audit. Hal ini menunjukkan masa perikatan yang lama Kantor Akuntan Publik merasa percaya dengan klien sehingga tidak mengembangkan strategi prosedur audit yang digunakan dan menurunkan kualitas audit.
3. Rotasi audit atau auditor switching tidak berpengaruh terhadap kualitas audit. Hal ini disebabkan karena pasar sebenarnya tidak terlalu peduli apakah auditor yang menyatakan opini audit pada laporan keuangan tahunan tersebut pernah dirotasi atau tidak.

4. Reputasi auditor tidak berpengaruh terhadap kualitas audit. Hal ini menujukkan bahwa kualitas audit yang tinggi tidak selalu berasal dari Kantor Akuntan Publik yang berafiliasi dengan KAP Big Four.

\section{Keterbatasan Penelitian}

Keterbatasan dari penelitian ini adalah sebagai berikut:

1. Penelitian ini hanya menggunakan empat variabel independen yaitu fee audit, audit tenure, rotasi audit dan reputasi auditor dengan satu variabel dependen yaitu kualitas audit.

2. Sampel yang digunakan dalam penelitian ini hanya perusahaan manufaktur yang terdaftar di Bursa Efek Indonesia dengan periode tahun laporan keuangan yang relatif singkat yaitu tiga tahun.

3. Variabel kualitas audit hanya diproksikan dengan opini going concern.

\section{Saran - Saran}

Dari keterbatasan - keterbatasan diatas maka untuk penelitian selanjutnya sebaiknya disarankan untuk:

1. Penelitian selanjutnya dapat menambahkan variabel independen seperti Client Importance, Komite audit dan Spesialisasi auditor.

2. Memperluas sampel penelitian dengan tidak hanya menguji perusahaan manufaktur tapi juga perusahaan di industri lainnya.

3. Menambahkan proksi lain untuk mengukur kualitas audit seperti akrual discressioner.

\section{Referensi}

[1] Aditama, IB Ananta dan I Made Karya Utama. 2015. "Pengaruh Audit Fee, Non Audit Services dan Audit Tenure pada Independendi Auditor". E-Jurnal Akuntansi Universitas Udayana Vol.13.3 (2015). 1164-1189.

[2] Agusti, Restu dan Pertiwi, Nastia Putri. 2013. "Pengaruh Kompetensi, Independensi, dan 
Profesionalisme Terhadap Kualitas Audit”. Jurnal Ekonomi Volume 21, nomor 3.

[3] Astrini, Novia Retno. 2013. “Analisis FaktorFaktor yang Mempengaruhi Perusahaan Melakukan Auditor Switching secara Voluntary”. Universitas Diponegoro. Skripsi.

[4] Badjuri, Ahmad. 2011. "Faktor-Faktor yang Berpengaruh Terhadap Kualitas Audit Auditor Independen Pada Kantor Akuntan Publik (KAP) di Jawa Tengah". Dinamika Keuangan dan Perbankan Vol. 2, No.2.

[5] Febriyanti, Ni Made Dewi dan I Made Mertha. 2014. "Pengaruh Masa Perikatan Audit, Rotasi Kap, Ukuran Perusahaan Klien, dan Ukuran Kap pada Kualitas Audit”. E-Jurnal Akuntansi Universitas Udayana. ISSN: 2302-85.

[6] Ghozali, Imam. 2006. "Aplikasi Analisis Multivariate dengan Program SPSS, Edisi Kedua”. Semarang: Badan Penerbit Universitas Diponegoro.

[7] Ghozali, Imam. 2011. "Aplikasi Analisis Multivariate dengan Program SPSS 19 Edisi Kelima”. Badan Penerbit Universitas Diponegoro. Semarang.

[8] Giri, Efraim Ferdinan. (2010). "Pengaruh Tenure Kantor Akuntan Publik (KAP) dan Reputasi KAP Terhadap Kualitas Audit: Kasus Rotasi Wajib Auditor di Indonesia”. Simposium Nasional Akuntansi XIII, Purwokerto.

[9] Hamid, Abdul. 2013. "Pengaruh Tenure KAP dan Ukuran KAP Terhadap Kualitas Audit (Studi Empiris pada Perusahaan Manufaktur yang Terdaftar di BEI)". Jurnal Akuntansi Negeri Padang. Volume 1 No.1

[10]Hanjani, Andreani. 2012. "Pengaruh Etika Auditor, Pengalaman Auditor, Fee Audit dan Motivasi Auditor Terhadap Kualitas Audit”. Universitas Diponegoro Semarang. Skripsi.

[11] Hartadi, Bambang. 2012. "Pengaruh Fee Audit, Rotasi KAP, dan Reputasi Auditor Terhadap Kualitas Audi di Bursa Efek Indonesia”. Jurnal Ekonomi dan Keuangan Indonesia. Volume 16 Nomor 1, Maret 2012: 84-103.

[12] Indah, Siti Nur. 2010. "Pengaruh Kompetensi dan Independensi Terhadap Kualitas Audit”. Universitas Diponegoro Semarang. Skripsi.

Riset Akuntansi dan Keuangan Indonesia, 3(1), 2018
[13] Kementerian Keuangan RI. (2008). Peraturan Menteri Keuangan Nomor: 17/Pmk.01/2008 tentang Jasa Akuntan Publik.

[14] Kurniasih, Margi dan Abdul Rohman. 2014. “ Pengaruh Fee Audit, Audit Tenure, dan Rotasi Auditor Terhadap Kualitas Audit”. Diponegoro Journal Of Accounting Volume 3, Nomor 3, tahun 2014.

[15]Law Tjun-Tjun-Tjun, Marpaung, Elyzabet Indrawati dan Setiawan, Santy (2012) "Pengaruh Kompetensi dan Independensi Auditor Terhadap Kualitas Audit”. Jurnal Akuntansi, 4 (1). Pp. 3356. ISSN 2085-8698.

[16] Mulyadi. (2009). “Auditing”. Jakarta: Salemba Empat.

[17] Nugrahanti, Yuvina. (2014). "Pengaruh Audit Tenure, Spesialisasi Kantor Akuntan Publik dan Ukuran Perusahaan Terhadap Kualitas Audit”. Universitas Diponegoro Semarang. Skripsi.

[18] Nuridin dan Widiasari. (2016). "Pengaruh Fee Audit dan Masa Perikatan Auditor Terhadap Kualitas Audit" ISSN 2338-4794. Vol.4, No.1 Januari 2016.

[19]Pamungkas, Yohanes Chrisostomus. (2014). "Pengaruh Fee Audit, Rotasi KAP, dan Reputasi Auditor Terhadap Kualitas Audit”. Jurnal Riset Manajemen dan Akuntansi. Vo.02. No.02, Hal: 59-67.

[20] Panjaitan, Clinton Marshal dan Anis Chariri. (2014). "Pengaruh Tenure, Ukuran KAP, dan Spesialisasi Auditor Terhadap Kualitas Audit”. Diponegoro Journal of Accounting Volume 3, Nomor 3.

[21]Permana, Klaudia Xary. (2012). "Pengaruh Masa Perikatan Audit dan Ukuran KAP Terhadap Kualitas Audit”. Universitas Diponegoro Semarang. Skripsi.

[22] Primadita, Indria, Fitriany. (2012). "Pengaruh Tenure Audit dan Auditor Spesialis Terhadap Informasi Asimetri: Perusahaan-Perusahaan yang Listing di Bursa Efek Indonesia (BEI)". Universitas Indonesia. Skripsi.

[23] Putri, Berty Wahyu. (2012). "Penentuan Kualitas Audit Berdasarkan Ukuran Kantor Akuntan Publik dan Biaya Audit". Jurnal Ilmiah Mahasiswa Akuntansi. Vol.1, No.4, Juli 2012. Surabaya. 
[24] Sinaga, Daud. (2012). "Analisis Pengaruh Audit Tenure, Ukuran KAP dan Ukuran Perusahaan Klien Terhadap Kualitas Audit”. Universitas Diponegoro Semarang. Skripsi.

[25] Siregar, Fitriany, Wibowo dan Anggraita. (2011). "Rotasi dan Kualitas Audit: Evaluasi Kebijakan Menteri Keuangan KMK.NO.423/KMK.6/2002 tentang Jasa Akuntan Publik jurnal Akuntansi dan Keuangan Indonesia”, Vol.8, No.1, Hal:117.

[26] Sugiyono. (2010). "Metode Penelitian Kuantitatif Kualitatif dan R\&D”. Bandung: Alfabeta. 